\title{
The factors that effect in vitro fertilization success in women of critical ages: "38-40 years"
}

\section{Illeri yaş kadınlarda tüp bebek başarısını etkileyen faktörler:38-40 yaş}

\author{
Ziya Kallem¹, Coskun Şimşir², Turgut Var $^{2}$
}

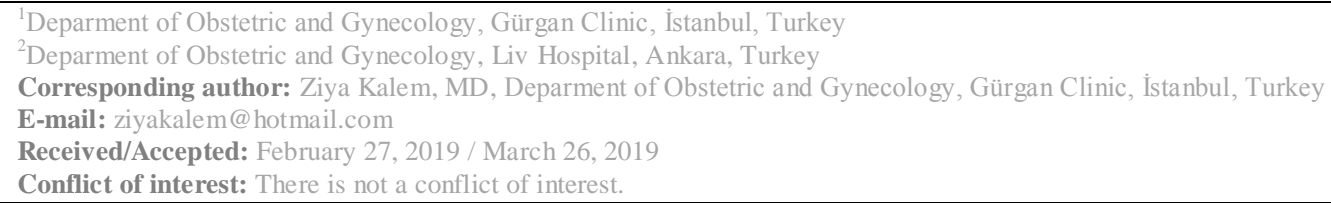

\section{SUMMARY}

Objective: The aim of this study is to assess the factors that affect IVF success in women of critical ages of " $38-40$ years".

Method: 468 women aged 38-40 years who were admitted for IVF between January 2013 to December 2017 were enrolled in the study. Ovarian stimulation characteristics, number of oocytes retrieved, number of embryos transferred and pregnancy rates ,cancellation rate, live birth rate were analyzed.

Results: The overall clinical pregnancy rate was $17.9 \%$. Cancellation rate was $22.4 \%$. The miscarriage rate was $25 \%$ (21/84).The live birth rate was $13.4 \%$ (63/468).Comparing the patients who did and did not achieve conception, we found statistically meaningful differences in terms of antral follicular count, retrieved oocyte count, number of embryos obtained, embryo count that was transferred,. Logistic regression analysis showed that the following factors were significantly related to higher pregnancy rates: number of embryos transferred, HMG usage in the stimulation protocol, basal FSH and blastocyst transfer.

Conclusions: The most important parameters which predict pregnancy in 38-40 year-old women are the number of transferred embryos, HMG usage in the stimulation protocol, low basal FSH level and blastocyst transfer.

Keywords: Women's age, IVF outcome, pregnancy rate, number of transferred embryos.

\section{ÖZET}

Amaç: Bu çalışmanın amacı 38-40 yaş aralığındaki kadınlarda IVF başarısını etkileyen faktörlerin araştırılmasıdır. Yöntem: Bu çalışmaya Ocak 2013-Aralık 2017 tarihleri arasında 38-40 yaş aralığında olup IVF için başvuran 468 kadın dahil edilmiştir.Ovarian stimulasyon karakteristikleri,toplanan oosit sayısı, transfer edilen embryo sayısı, siklus iptal oranları, gebelik ve canlı doğum oranları analiz edilmiştir.

Bulgular: Toplam gebelik oranı\%17.9 olarak hesaplanmıştır.Siklus iptal oranı\%22.4, gebelik kaybı oranı \% 25 , canlı doğum oranı \%13.4 olarak bulunmuştur. Gebe kalan ve gebe kalamayan hasta grupları karşılaştırıldığında antral folikül sayısı,toplanan oosit sayısı, elde edilen ve transfer edilen embryo sayıları anlamlı farklılıklar göstermiştir.Logistic regresyon analizi sonuçlarına göre artan gebelik oranları ile ilişkili faktörler:Transfer edilen embryo sayısı, stimulasyon protokolünde HMG kullanımı, basal FSH değeri ve blastokist transferi yapılmış olmasıdır.

Sonuç: 38-40 yaş arası kadınlarda gebelik başarısını predikte eden en önemli parametreler transfer edilen embryo sayıs1, stimulasyon protokolünde HMG kullanımı, bazal FSH seviyesi ve blastokist transferidir.

Anahtar sözcükler: Kadın yaşı, IVF başarısı, gebelik oranı, transfer edilen embryo sayısı

\section{INTRODUCTION}

Late marriages and women's career plans in modern day life result in the postponement of their childbirth plans. However, pregnancy rates fall towards late $30 \mathrm{~s}$, both by spontaneous conception and by assisted reproductive techniques $^{1,2}$.Age is the single most important factor in achieving pregnancy via assisted reproductive techniques ${ }^{2}$. As patients become 
older, conception rates fall. Although there is no universal definition of advanced reproductive age in women, infertility becomes more frequently an issue after the age of $35^{3}$.

Starting from age 38 , the reduction of ovarian follicles accelerates irreversibly ${ }^{4}$.While some studies claim that advanced reproductive age starts at 37-38, others maintain that it starts after age $40^{5}$.Therefore, studies generally make a distinction between either under and over 37-38, or under and over $40^{6-11}$.

The aim of the present study is to assess the factors that affect IVF success during the transition period of women life of 38-40 years.

\section{MATERIAL AND METHODS}

The women aged 38-40 years who were admitted for IVF from January 2013 to December 2017 were enrolled in the study. Four hundred sixty eight IVF cycles (patients) were evaluated. This cross sectional study was approved by local ethics committee and conducted in accordance with the basic principles of the Helsinki Declaration.

Ovarian stimulation characteristics, number of oocytes retrieved, number of transferred embryos and pregnancy rates were analyzed. IVF indications included tubal factor, hormonalanovulatory disorder, sub-fertile male factor $(\geq 5$ million total progressive motile spermatozoa per milliliter), endometriosis or unexplained infertility. Study inclusion criteria were as follows:

1- A basal FSH hormone level less than 12 IU/L,

2- Patients between 38-40 years of age,

3- Patients who have first IVF cycle, and

4- Long and microdose flare up protocol with GnRH-a and $\mathrm{rFSH}$.

Exclusion criteria were:

1- Patients younger than 38 years and older than 40 years,

2- Patients with severe male factor $(<5$ million motile spermatozoa per milliliter and which required TESE),

3-Patients with endocrine disorders and systemic disease,

4-Women with uterine anomaly or uterine fibroids and hydrosalpinges, and

5-Frozen-thawed cycles .

\section{Ovulation induction:}

Ovarian stimulation was performed by one of the following protocols depending on previous or estimated ovarian response:

1- Long desensitizing protocol using the gonadotropin-releasing hormone $(\mathrm{GnRH})$ agonist Lucrin (Lucrin Daily ${ }^{\circledR}$, Abbott, Johannesburg ) $15 \mathrm{u} /$ day was given subcutaneously from the midluteal phase of the preceding cycle (days 21-23). Gonadotropins were started on day 2 of the cycle.

2- In microdose flare protocol, the treatment started with oral contraceptives. Two days after the end of oral contraceptive, GnRH analogs were administered at microdoses (leuprolide acetate $50 \mu \mathrm{g})$ subcutaneously twice a day. Gonadotropins were started 2 days later.

Ovulation induction protocols involved human menopausal gonadotropin (HMG) (Menogon, Ferring Pharmaceuticals) or Recombinant Fsh (Gonal F, Merck Serono), or a combination of both. Dose alterations were performed on the 4th day of stimulation and continuing days according to the sonographic findings and circulating estradiol $\left(\mathrm{E}_{2}\right)$ levels. Ovulation was induced by a subcutaneus injection of $250 \mu \mathrm{g}$ recombinant human chorionic gonadotropin (hCG) (Ovitrelle $\mathbb{R}$, Merck Serono) when at least 3 follicles reached a diameter of $18 \mathrm{~mm}$. Oocyte pick up (OPU) was performed 34-36 hours after hCG injection. ICSI was performed for all metaphase II oocytes. Embryo transfer was performed under ultrasound guidance on day of 2,3 or 5 for patients. Embryo transfer was determined based on the American Society for Reproductive Medicine (ASRM) guidelines $^{12}$ and performed using Wallace catheter (Edwards-Wallace Catheter; Marlow Technologies, Willoughby, $\mathrm{OH})$. All patients received intravaginal progesterone (Crinone gel) support. Clinical pregnancy was defined as visualization of gestational sac by vaginal ultrasound.

Miscarriage was defined as a pregnancy lost before 20 weeks of gestation.Live birth was defined as a pregnancy resulting in a delivery of a viable infant.Cancellation was defined as patients' cycle did not reach oocyte retrieval or in whom oocyte retrieval was performed but no oocytes were retrieved or fertilization failure . 


\section{Statistical analysis :}

Data analysis was performed by using SPSS for Windows, version 11.5 (SPSS Inc., Chicago, IL, United States). While, continuous data were shown as mean \pm standard deviation, otherwise, number of cases and percentages were used for nominal variables. Continuous variables were compared by Student's t or Mann Whitney U test, where applicable. Nominal data were analyzed by Chi-square or Fisher's exact test, where appropriate. Multiple Backward LR Logistic Regression Analyses were used for determining the predictors which mostly affected on pregnancy. Any variable whose univariable test had a $\mathrm{p}$ value $<0.05$ was accepted as a candidate for the multivariable model along with all variables of known clinical importance. Odds ratio and $95 \%$ CIs for each variables were also calculated. A $\mathrm{p}$ value less than 0.05 was considered statistically significant.

\section{RESULTS}

Four hundred sixty eight IVF cycles (patients) were evaluated. Their mean age was $38.7 \pm 0.77$. The distribution of patients with respect to reason for infertility was as follows: Unexplained $69.3 \%$, male factor $16.7 \%$, tubal factor $7.1 \%$, endometriosis $3.8 \%$ and mixed factor $3.2 \%$. The overall clinical pregnancy rate (PR) was $17.9 \%$ (84/468). The miscarriage rate (MR) was $25 \%$ (21/84). The live birth rate (LBR) was $13.4 \%$ (63/468) .Cancellation rate (CR) was $22.4 \%$. Of the 468 patients, $27(5.7 \%)$ did not reach oocyte retrieval; of the $25(5.3 \%)$ in whom oocyte retrieval was performed, no oocytes were retrieved; and fertilization failure occurred in 53 $(11.3 \%)$ patients. Other clinical characteristics of the patients are presented in Table 1.

Table 1: Characteristics of IVF cycles

\begin{tabular}{|l|l|}
\hline Number of patients & 468 \\
\hline Age(years) & $38.7 \pm 0.77$ \\
\hline Cancellation rate & $22.4 \%(105 / 468)$ \\
\hline Number of gonadotropin ampules & $44.0 \pm 13.5$ \\
\hline Length of stimulation(days) & $10.1 \pm 2.0$ \\
\hline $\begin{array}{l}\text { Peak estradiol level on day of HCG } \\
\text { administration(pmol/l) }\end{array}$ & $1965.5 \pm 1097.8$ \\
\hline $\begin{array}{l}\text { Number of follicles }>14 \text { mm on day of HCG } \\
\text { administration }\end{array}$ & $6.7 \pm 4.1$ \\
\hline Number of oocytes retrieved & $6.3 \pm 4.2$ \\
\hline Fertilization rate & $64.3 \pm 31.7$ \\
\hline Number of embryos transferred & $3.0 \pm 2.6$. \\
\hline Clinical pregnancy rate per patient & $17.9 \% \quad(84 / 468)$ \\
\hline Miscarriage rate & $25 \% \quad(21 / 84)$ \\
\hline Live birth rate per patient & $13.4 \% \quad(63 / 468)$ \\
\hline
\end{tabular}

Data are expressed as mean \pm SD or $\mathrm{n}(\%)$. 
Table 2: Comparison between achieved clinical pregnancy and non-pregnant groups

\begin{tabular}{|c|c|c|c|c|c|c|c|}
\hline & $\begin{array}{l}\text { Clinical } \\
\text { pregnancy } \\
\text { group } \\
(\mathrm{n}=84)\end{array}$ & $\begin{array}{l}\text { No pregnancy } \\
\text { group } \\
(n=384)\end{array}$ & $\begin{array}{l}\text { Odds } \\
\text { Ratio }\end{array}$ & Wald & $\begin{array}{l}\mathbf{p} \\
\text { Value }\end{array}$ & $\begin{array}{l}\% 95 \\
\text { Confidence } \\
\text { Interval }\end{array}$ & \\
\hline & & & & & & Min & Max \\
\hline Patient age(year) & $38.3 \pm 0.5$ & $38.7 \pm 0.7$ & 0.852 & 4,977 & 0.016 & 0,207 & 18,269 \\
\hline Antral follicle count & $8.1 \pm 4.1$ & $5.9 \pm 2.9$ & 1,696 & 0,554 & 0.012 & 0,422 & 6,811 \\
\hline Basal FSH level(mIU/mL) & $7.9 \pm 1.8$ & $9.2 \pm 2.0$ & 0,857 & 11,584 & 0.001 & 0,784 & 0,937 \\
\hline Basal E2 level(pg/mL) & $41.2 \pm 18.7$ & $55.0 \pm 33.3$ & 0,259 & 9,977 & 0.013 & 0,112 & 0,599 \\
\hline Number of gonadotropin ampules used & $38.1 \pm 11.1$ & $45.3 \pm 13.6$ & 0,446 & 3,819 & 0.011 & 0,199 & 1,002 \\
\hline Length of stimulation(day) & $9.6 \pm 2.0$ & $10.2 \pm 2.0$ & 1,307 & 3,673 & 0.011 & 0,967 & 4,171 \\
\hline $\begin{array}{l}\text { Peak E2 level on the day of HCG } \\
\text { administration }(\mathrm{pg} / \mathrm{mL})\end{array}$ & $2292.1 \pm 1062.6$ & $1892.9 \pm 1093.6$ & 1,590 & 8,403 & $<0,001$ & 1,286 & 1,965 \\
\hline $\begin{array}{l}\text { Number of follicles }>14 \mathrm{~mm} \text {, on day of } \\
\text { HCG administration }\end{array}$ & $8.8 \pm 4.0$ & $6.2 \pm 3.9$ & 0,805 & 5,491 & 0.013 & 0,672 & 0,965 \\
\hline Number of oocytes retrieved & $9.1 \pm 4.2$ & $5.7 \pm 3.9$ & 0,981 & 6,878 & 0.015 & 0,967 & 0,995 \\
\hline Fertilization rate $(\%)$ & $70.4 \pm 22.9$ & $62.9 \pm 33.3$ & 0,999 & 5,548 & 0.082 & 0,999 & 1,000 \\
\hline Number of embryos obtained & $4.8 \pm 2.6$ & $2.6 \pm 2.5$ & 1,348 & 5,117 & 0.014 & 1,041 & 1,746 \\
\hline Number of embryos transferred & $1.9 \pm 0.1$ & $1.4 \pm 0.6$ & 0,909 & 0,086 & 0.019 & 0,479 & 1,723 \\
\hline $\begin{array}{l}\text { Peak E2 levels/number of follicles }>14 \\
\mathrm{~mm} \text {, on day of HCG }\end{array}$ & $277.7 \pm 104.1$ & $340.9 \pm 154.5$ & 3,046 & 6,179 & 0.011 & 2,203 & 4,627 \\
\hline $\begin{array}{l}\text { Peak E2 levels/number of oocytes } \\
\text { retrieved }\end{array}$ & $291.4 \pm 149.7$ & $404.5 \pm 255.2$ & 9,247 & 10,689 & 0.013 & 2,437 & 35,084 \\
\hline
\end{tabular}

*Significant at $\mathrm{p}<0.05$. Data are expressed as mean \pm SD .

Comparing the patients who did and did not achieve conception, we found statistically meaningful differences in terms of antral follicular count, basal FSH level, basal E2 level, gonadotropin dose and kind, protocol type, stimulation duration, Peak E2 level on the day of HCG administration, number of follicles $>14 \mathrm{~mm}$ on day of HCG administration, retrieved oocyte count, number of embryos obtained, embryo count that was transferred, transfer day, Peak E2 levels/number of follicles $>14 \mathrm{~mm}$ on day of HCG administration and Peak E2 levels/number of oocytes retrieved (Table 2).

No differences were found between the groups as regards BMI, duration of infertility, reasons for infertility, basal LH levels, HCG day endometrial thickness, HCG day progesterone levels and fertilization rates. With respect to the type of gonadotropin used, pregnancy rates in patients who only received HMG (15.3\%) and HMG plus rFSH $(21.2 \%)$ were statistically higher than in those who received only $\mathrm{rFSH}(4.5 \%)(\mathrm{p}=0.04)$. While $21 \%(60 / 282)$ of the patients who were administered long protocol achieved conception, only $12.9 \%(24 / 186)$ of the patients who were administered microdose flare-up protocol achieved it. When compared, long protocol patients had meaningfully higher pregnancy rates $(p=0.024)$. When the patients were evaluated with respect to transfer day, pregnancy rate in patients who had transfer on day 5 was $62.5 \%$ (15/24), and the rates in patients who had transfer on days 2 and 3 were $18.5 \%(30 / 162)$ and $22 \%$ (39/177), respectively. The pregnancy rate in patients who had transfer on day 5 was statistically meaningful $(\mathrm{p}=0.014)$. 
Logistic regression analysis showed the following factors were significantly related to higher pregnancy rates: number of embryos transferred, HMG usage in the stimulation protocol, basal FSH and blastocyst transfer.

\section{DISCUSSION}

In this study, we assessed the factors that influence IVF success among patients aged between 38-40. As a result, the most important parameters associated with high pregnancy rates seemed to be the number of embryos transferred, HMG usage in the stimulation protocol, basal FSH and blastocyst transfer.

In IVF cycles, advanced age has negative effects such as decreased response to $\mathrm{COH}$, lower fertilization and implantation rates, and high cancellation rates ${ }^{13}$.

In most studies, pregnancy rates were found to be significantly lower among patients over 35 years and even lower among those aged over 40 ${ }^{14,15}$.Further, despite clinical identification of pregnancy, $14 \%$ of patients fail to achieve live birth under the age of $35 ; 19 \%$ will fail to achieve it between ages $35-37 ; 25 \%$ between ages $37-40$; and $40 \%$ after age $40{ }^{16}$.

Studies about ovarian reserve have yielded various cut off values for age. Saldeen found a mean age of 37 in the poor responder group ${ }^{6}$ ,while Fontaine concluded it was $36^{17}$. MedenVrtovec evaluated patient groups aged under and over $38^{18}$. As can be seen, studies mostly choose to investigate patients under and over $37-38$ or under and over $40^{7-11}$.

Our clinical pregnancy rate is $17.9 \%$. This rate is similar to the rate $(18 \%)$ of the patients over 38 in the study of Abdalla ${ }^{19}$. This rate is $40 \%$ for those patients under 38. LBR also decreases with the age increase. This rate is $32.4 \%$ for the normoresponder women under 38 and $12.1 \%$ for the women over $38^{19}$. In our study, this rate was found as $13.4 \%$.

In the study of Abdalla, while CR before OPU was $4 \%$ for the normoresponder patients who are under 38 , this rate was $10 \%$ for those who are over $38^{19}$. In the study of Saldeen, while CR after OPU was $13.2 \%$ for the normoresponder patients who are over 37 , this rate was $10.5 \%$ for those who are under $37^{6}$. CR increases by the age. Decrease of quality of oocyte and embryo due to the aging leads to reduced pregnancy rate ${ }^{20}$. With the age increased, lower ovarian response is one of the most effective factors accountable for the non-development of oocytes ${ }^{21}$. In fertilization failure, failed oocyte activation and maternal chromosome defects come to the foreground ${ }^{22}$. Our cancellation rate was higher than these studies.

Miscarriage rate also increases by age because of the DNA fragmentation and apoptotic deaths increase $^{23}$. Furthermore, aneuploidy in oocytes also increases ${ }^{24}$.In the study of Abdalla, MR was found $20 \%$ for the patients under 38 however this rate increased to $35 \%$ for those over the age 38 . In our study, our MR was found as $25 \%$. This rate is nearer to that of the patient group under 38 in the study of Abdalla ${ }^{19}$.

Klipstein reported in a study conducted on a group of patients aged 40 years and older that the most important factor that increases pregnancy rates was a high number of embryos to be transferred and embryos suitable for cryopreservetation ${ }^{25}$. Opsahi showed that the number of transferrable embryos predicted successful pregnancy outcomes among patients aged 39 and older with normal ovarian reserve(26). In our study too, logistic regression showed that the most important factor that increases pregnancy rates was the number of embryos transferred. In contrast to our study, Valeva claims that single and double embryo transfer did not result in different pregnancy outcomes in the 36-39 age group ${ }^{27}$.

The effects of HMG usage or adding LH to FSH on IVF outcomes are debatable. Fabregues reports that his patients with a mean age of 38 did not have increased ovarian response to $\mathrm{LH}$ addition in assisted reproductive technologies ${ }^{28}$. On the other hand, Marrs and Humaidan claim that LH addition increased positive IVF outcomes in patients aged 35 and over $^{29,30}$. In our study of 38-40 year-old patients, pregnancy rates with the usage of HMG alone or joint usage of $\mathrm{HMG}$ and $\mathrm{rFSH}$ were statistically higher than the rates in patients in whom $\mathrm{rFSH}$ was used alone. Logistic regression analysis also showed that HMG usage was the second most important parameter after the number of embryos transferred in stimulation protocol.

It is known that as basal FSH levels increase, ART success decreases, however, there is not an exact cut-off value to discriminate normal or high $\mathrm{FSH}^{31}$. FSH and age were assessed together in ART cycles and age was reported to be the single most important factor in IVF outcome. Under the age of 38, FSH elevation did not affect pregnancy and live birth rates, while after the age of $38, \mathrm{FSH}$ 
elevation statistically decreased these rates. This study also claimed that fertilization rate was independent of FSH elevation and age(18). In Akende's study, cancellation rate was minimal among younger age groups, while it increased rapidly after age 35 and had a more significant relationship with FSH in advanced ages ${ }^{32}$. In this study, the age of patients in cancelled cycles was more advanced and basal FSH levels were statistically higher. Age and FSH values were correlated in some studies ${ }^{32,33}$. In our study too, basal FSH value was found to be one of the most important parameters predicting pregnancy in the 38-40 age group.

In our study, blastocyst transfer was found to more meaningfully predict pregnancy when compared to $2^{\text {nd }}$ and $3^{\text {rd }}$ day transfers. Similar to our study, Milki found blastocyst transfer to be more effective than $3^{\text {rd }}$ day transfer in his 2002 study ${ }^{9}$.

Strenght of this study is high patients number and this is the first study in literature that investigated the factors that effect in vitro fertilization success in women of advanced ages in Turkish population. Most important limitation of the study is that, IVF procedures is realized in various IVF clinics, it would be more valuable if all procedure were take places in same center.

In conclusion; the age of the patient is an important factor for assessment of infertility treatments and it is our major reference point that determines stimulation protocol, drug type and dose to be selected. While the patient group aged between 38- 40 carry certain similar characteristics to young patients regarding response to IVF, they exhibit characteristics of advanced age patients regarding other aspects. We are of the opinion that the most important parameters which predict pregnancy in 38-40 year-old women are the transfer of a high number of embryos, HMG usage in the stimulation protocol, low basal FSH level and blastocyst transfer. In order to find an advanced age cut-off value, it may be appropriate to conduct a study to investigate the ages of 38,39,40 separately.

\section{REFERENCES}

1. Crawford, N. M., \& Steiner, A. Z. Age-related infertility. Obstetrics and Gynecology Clinics 2015; 42(1),15-25.

2. Donnez, J., Dolmans, M. M., Pellicer, A., DiazGarcia, C., Ernst, E., Macklon, K. T., \& Andersen, C. Y. Fertility preservation for agerelated fertility decline. The Lancet, 2015; 385(9967), 506-507.
3. Eniola, O. W., Adetola, A. A., \& Abayomi, B. T. A review of Female Infertility; important etiological factors and management. Journal of Microbiology and Biotechnology Research 2017; 2(3), 379-385.

4. Tal, R., \& Seifer, D. B. Ovarian reserve testing: a user's guide. American journal of obstetrics and gynecology 2017; 217(2), 129-140.

5. Gleicher N, Weghofer A, Barad D. Too old for IVF: are we discriminating against older women? J Assist Reprod Genet 2007; 24(12), 639-644.

6. Saldeen P, Kallen K, Sundstram P. The probability of successful IVF outcome after poor ovarian response. Acta Obstet Gynecol Scand 2007; 86(4), 457-461.

7. Hsieh Y.Y, Huang C.C, Cheng T.C, Chang C.C, Tsai H.D, Lee M.S. Laser-assisted hatching of embryos is better than the chemical method for enhancing the pregnancy rate in women with advanced age. Fertil Steril 2002;78(1), 179-182.

8. Jirge, P. R. Poor ovarian reserve. Journal of Human Reproductive Sciences 2016;9(2),63.

9. Milki A.A, Hinckley M.D, Behr B. Comparison of blastocyst transfer to day 3 transfer with assisted hatching in the older patient. Fertil Steril 2002;78(6), 1244-1247.

10.Sbracia M, Farina A, Poverini R, Morgia F, Schimberni M, Aragona C.Short versus long gonadotropin-releasing hormone analogue supression protocols for superovulation in patients $\geq 40$ years old undergoing intracytoplasmic sperm injection. Fertil Steril 2002; 84(3),644-648.

11. Tsafrir A. Retrospective analysis of 1217 IVF cycles in women aged 40 years and older. Reprod Biomed Online 2007;14(3),348-355.

12. Pasqualini RS, Quintans CJ. Clinical practice of embryo transfer. Reprod Biomed Online. 2002; 4(1),83-92.

13. Sunderam, S., Kissin, D. M., Crawford, S. B., Folger, S. G., Jamieson, D. J., Warner, L., \& Barfield, W. D. Assisted reproductive technology surveillance-United States, 2014. MMWR Surveillance Summaries 2017; 66(6), 1 .

14. Fernandez-Shaw, S., Cercas, R., Brana, C., Villas, C., \& Pons, I. Ongoing and cumulative pregnancy rate after cleavage-stage versus blastocyst-stage embryo transfer using vitrification for cryopreservation: impact of age on the results. Journal of assisted reproduction and genetics 2015; 32(2),177-184.

15. Kalem, M. N., Kalem, Z., Sarı, T., Ateş, C., \& Gürgan, T. (2016). Effect of body mass index and age on in vitro fertilization in polycystic ovary syndrome. Journal of the Turkish German Gynecological Association, 17(2), 83.

16. Centers for Disease Control and Prevention, American Society for Reproductive Medicine, 
Society for Assisted Reproductive Technology, RESOLVE. 1999 Assisted reproductive technology success rates. Atlanta, GA: Centers for Disease Control and Prevention, 2001.

17. Fontaine J.G. Age and ovarian reserve are distinct predictive factors of cycle outcome in low responders. RBM Online 2005;10(1),94-99.

18. Meden-Vrtovec H. Ovarian aging and infertility. Clin Exp Obstet Gynecol 2004; 31: 5-8. 19. Abdalla H, Thum M.Y.An elevated basal FSH reflects a quantitative rather than qualitative decline of the ovarian reserve. Human Reprod 2004; 19(4),893-898.

20. Fong, S. L., Baart, E. B., Martini, E., Schipper, I., Visser, J. A., Themmen, A. P. N., ... \& Laven, J. S. E. Anti-Müllerian hormone: a marker for oocyte quantity, oocyte quality and embryo quality?. Reproductive biomedicine online 2008; 16(5),664-670.

21. Swain JE, Pool TB. ART failure:oocyte contributions to unsuccessful fertilization.Hum Reprod Update 2008;14(5),431-446

22. Boucret, L., Chao De La Barca, J. M., Moriniere, C., Desquiret, V., Ferre-L'Hotellier, V., Descamps, P., ... \& May-Panloup, P. (2015). Relationship between diminished ovarian reserve and mitochondrial biogenesis in cumulus cells. Human reproduction 2015;30(7),1653-1664. 23. Meldrum, D. R., Casper, R. F., Diez-Juan, A., Simon, C., Domar, A. D., \& Frydman, R. Aging and the environment affect gamete and embryo potential: can we intervene? Fertility and sterility 2016;105(3), 548-559.

24.Pellestor F,Andreo B,Arnal F. et al.Maternal aging and chromosomal abnormalities:new data drawn from in vitro unfertilized human oocytes. Human Genetics 2003;112(2),195-203

25.Klipstein S, Regan M, Ryley D.A, Goldman M.B, Alper M.M, Reindollar R.H. One last chance for pregnancy: a review of 2705 invitro fertilization cycles initiated in women age 40 years and above. Fertil Steril 2005;84(2), 433445.
26. Opsahi MS, Blauer KL, Black SH, Lincoln SR, Thorsell L, Sherins RJ. The number of embryos available for transfer predicts successful pregnancy outcome in women over 39 years with normal ovarian hormonal reserve testing. J Assist Reprod Genet 2001;18(10), 551-556.

27. Veleva Z, Vilska S, Hyden-Granskog C, Tiitinen A, Tapanainen S.J, Martikainen H. Elective single embryo transfer in women aged 36-39 years. Hum Reprod 2006;21(8),2098-2102.

28. Fabregues F, Creus M, Penarrubia J, Manau D, Vanrell J.A, Balasch J. Effects of recombinant human luteinizing hormone supplementation on ovarian stimulation and the implantation rate in down-regulated women of advanced reproductive age. Fertil Steril 2006;85(4), 925-931.

29. Marrs R, Meldrum D, Muasher S, Schoolcraft W, Werlin L, Kelly E.Randomized trial to compare effect of recombinant human FSH(follitrophin alfa) with or without recombinant LH in women undergoing assisted reproduction treatment. Reprod Biomed Online 2004; 8(2), 175-182.

30. Humaidan P, Bungum L, Bungum L, Yding Andersen C. Effects of recombinant LH supplementation in women undergoing assisted reproduction with $\mathrm{GnRH}$ agonist down-regulation and stimulation with recombinant FSH an opening study. Reprod Biomed Online 2004; 8(6), 635643.

31. Esposito MA, Coutifaris C and Barnhart KT. A moderately elevated day 3 FSH concentration has limited predictive value, especially in younger women. Hum Reprod 2002;17(1), 118-123.

32. Akande V.A, Keay S.D, Hunt L.P, Mathur R.S, Jenkins J.M, Cahill D.J. The practical implications of a raised serum FSH and age on the risk of IVF treatment cancellation due to a poor ovarian response. J Assist Reprod Genet 2004; 21(7), 257-262.

33. Yilmaz, N., Kara, M., Coskun, B., Kaba, M., Erkilinc, S., Yenicesu, O., \& Erkaya, S. (2017). Perinatal outcomes and cost-effectivity of the assisted reproduction pregnancies with advanced age: A retrospective analysis. Journal of Obstetrics and Gynaecology, 37(4), 450-453. 